\title{
Community structures of soil animals and survival of land snails on an island of the Ogasawara Archipelago
}

\author{
Motohiro Hasegawa( ${ }^{(1)}$, Shinji Sugiura ${ }^{(2)}$, Masamichi T. Ito ${ }^{(3)}$, Aska Yamaki( ${ }^{(4)}$, Keiko Hamaguchi(5), \\ Toshio Kishimoto(6) and Isamu Okochi(2)
}

\begin{abstract}
(1)Forestry and ForestProducts Research Institute(FFPRI), Kiso Experimental Station,Fukushima5473,Kiso, Nagano,397-0001 Japan.E-mail:motohiro@ffpri.affrc.go.jp ${ }^{(2)}$ FFPRI, Tsukuba, Ibaraki 305-8687 Japan. ${ }^{(3)}$ Surugadai University, Department of Economics, Asu 698, Hannou, Saitama, 357-8555 Japan. ${ }^{(4)}$ Yokohama National University, Faculty of Environment and Information Sciences, 79-7 Tokiwadai, Hodogaya, Yokohama, Kanagawa 240-8501 Japan. ${ }^{(5)}$ FFPRI, Kansai Research Center, Nagai-Kyutaro 68, Momoyama-cho, Fushimi-ku, Kyoto, Kyoto 612-0855 Japan. (6)Japan Wild Life Research Center, Shitaya 3-10-10, Taito, Tokyo 110-8676 Japan.
\end{abstract}

\begin{abstract}
On Chichijima, one of the Ogasawara (Bonin) Islands located in the Western Pacific Ocean, land snails have declined, the suggested cause being predation pressure by an invasive flatworm (Platydemus manokwari). Soil fauna were investigated in areas where the snail survives, and where it has become extinct. Much of the fauna, dominated by introduced earthworms and ants, was undiminished, however, one undescribed but endemic carabid (Badister sp.), which selectively feeds on land snails, was absent in snail-extinct areas. The invasive flatworm P. manokwari has been reported to feed also on the carcasses of earthworms, as well as on live snails, and is therefore expected to occur in most parts of Chichijima Island. Among other groups, the density of isopods (also dominated by exotic species) was very low, in comparison with the reported ones 30 years ago. Community structure is currently reflected by dominance of earthworms and ants, decline of endemic isopods, and a high frequency of introduced or alien species.

Index terms: Badister, Platydemus manokwari, Formicidae, Isopoda, Oligochaeta, Platyhelminthes.

\section{Estruturas de comunidades de animais de solo e sobrevivência dos caracóis terrestres numa ilha do Arquipélago Ogasawara}

\begin{abstract}
Resumo - Em Chichijima, uma das ilhas do Arquipélago Ogasawara (Bonin), localizado no Oceano Pacífico Ocidental, o número de caracóis terrestres diminuiu, e a causa provável é a predação por uma planária invasora (Platydemus manokwari). A fauna edáfica foi avaliada nas áreas onde o caracol sobreviveu e onde se extinguiu. Grande parte da fauna, dominada inicialmente por minhocas e formigas, não diminuiu; contudo, um carabídeo endêmico e não descrito (Badister sp.), que se alimenta de caracóis terrestres, não estava presente nas áreas em que o caracol foi extinto. Sabe-se que a planária invasiva $P$. manokwari se alimenta não só das carcaças das minhocas, mas também de caracóis vivos, e por isso habita a maior parte da Ilha Chichijima. Entre outros grupos, a densidade de isópodos (também dominados por espécies exóticas) foi muita baixa, em comparação aos relatos feitos 30 anos antes. A estrutura da comunidade é refletida atualmente pela dominância de minhocas e formigas, declínio de isópodos endêmicos, e uma alta frequência de espécies introduzidas ou exóticas.
\end{abstract}

Termos para indexação: Badister, Platydemus manokwari, Formicidae, Isopoda, Oligochaeta, Platyhelminthes.

\section{Introduction}

Invasive species have become a major research issue in ecology, but the effects and implications of invasive species on belowground terrestrial ecosystems have not been unraveled (González et al., 2006). Island systems, with depauperate biotas, assist at the identification of impacts on communities and ecosystem functions at species level (Wardle, 2002).
Ninety-five species of land snails from Ogasawara (Bonin) Islands have been recorded, of which more than 90 percent are endemic to the islands (Chiba et al., 2007). However, most of the endemic species have already become extinct or endangered in Chichijima (Chiba et al., 2007). Predation pressure by an invasive flatworm (Platydemus manokwari) is considered a possible cause of the land snails decline (Okochi et al., 2004; Ohbayashi et al., 2005, 2007; Sugiura et al., 
2006). Soil faunas on Chichijima have been investigated at intervals in the past (Aoki \& Harada, 1978; Ishizawa \& Takehara, 2001), specifically some endemic species (Aoki, 1978; Nunomura, 1991). However, no studies have been conducted on the decline of snails, for which relationship may be attributed to invasive animals. Although predation by the flatworm is limited to a few groups of fauna (mainly land snails), other taxa may be impacted indirectly on local extinction of the snails.

The aim of this study was to investigate the more general soil fauna, in areas where the snail survived and in areas where it has become extinct in Chichijima Island.

\section{Materials and Methods}

Four representative groups of soil macro-fauna: earthworms (Annelida: Clitellata: Haplotaxida); isopods (Arthropoda: Isopoda); beetles (Arthropoda: Insecta: Coleoptera), and ants (Arthropoda: Insecta: Formicidae), and two groups of soil mesofauna springtails (Arthropoda: Hexopoda: Collembola) and oribatid mites (Arthropoda: Arachnida: Oribatida) were compared between sites where the land snail survives and where it has been exterminated. In addition, the biomass of earthworms in Chichijima Islands was measured to assess the potential resource it represents for flatworms after the land snail is exterminated.

The Ogasawara (Bonin) Islands are located in the Western Pacific Ocean, about 1,000 km south of the mainland of Japan. The study was conducted close to Ogasawara, Tokyo Metropolitan Prefecture, a village on Chichijima, the largest of the Ogasawara Islands $\left(27^{\circ} 05^{\prime} \mathrm{N}, 142^{\circ} 12^{\prime} \mathrm{E}\right)$ during 2005 . The climate is subtropical with $23.2^{\circ} \mathrm{C}$ mean annual temperature and 1,292 $\mathrm{mm}$ annual precipitation 1987-1988 (Toyoda, 2003). We established ten plots at a forest site, including three ones where land snails survived (survival plots), and seven where land snails had been exterminated (extermination plots). Plot selection followed surveys for snails by Ohbayashi et al. (2007). The dominant trees of these sites are Livistona chinensis $\mathrm{R}$. Br. var. boninensis and Pandanus boninensis. Other significant vegetation on the island includes Schima mertensiana, Distylium lepidotum and Casuarina equisetifolia.

However, plots selected for sampling were dominated by L. chinensis $\mathrm{R}$. Br. var. boninensis and P. boninensis, and were, therefore, botanically uniform.
In June, a soil macrofauna survey was conducted on 10 plots (three of survival and seven of extermination) and, in November, on 8 plots (three of survival and five of extermination). Six quadrates: $(25 \times 25 \mathrm{~cm}$ each) were set at 5-m intervals, along a $25-\mathrm{m}$ transect line in each plot, and the litter layer and topsoil (up to 15-cm depth) were collected from each quadrate. In November, the weight of the litter layer and water content [(wet weight - dry weight) dry weight] were also determined. Soil animals were collected by hand sorting. Animals were preserved in $5 \%$ formalin (earthworms, isopods) or $80 \%$ ethanol (all the others), and were sorted into taxonomic groups under a stereomicroscope. The biomass of earthworms was estimated using material from $5 \%$ formalin after drying for 72 hours at $60^{\circ} \mathrm{C}$.

A soil mesofauna survey was conducted in six plots (three of survival and three of extermination). A $100 \mathrm{~mL}$ soil sample $\left(20 \mathrm{~cm}^{2} \times 5 \mathrm{~cm}\right.$ in depth), including litter layer, was taken with a cylindrical core sampler at each of the ten points set at 5-m intervals, along a separate transect $(45 \mathrm{~m})$ in each plot. The samples were put into Tullgren funnels within a few hours of sampling and extracted for three days under an electric heater kept at $35^{\circ} \mathrm{C}$. Specimens were preserved in $80 \%$ ethanol. Collembolans and oribatid mites were identified to species level and counted under a microscope.

To compare parameters between the two types of plots, we used generalized linear models (GLM), with the assumption of negative binominal distribution for the number of individuals, following Sileshi (2008). We also used GLM for species richness, with the assumption of Poisson distribution and for the comparison of the earthworm biomasses with the assumption of Gaussian distribution ( $\mathrm{R}$ version 2.4.1; R Development Core Team, 2006). Principal Component Analysis (PCA) with Canoco for Windows, Version 4.5 (Ter Braak \& Ŝmilauer, 2002) were used to compare species composition between sites. In PCA, only those species with a total count of at least three individuals were used (or at least two individuals for Coleoptera). Population data were transformed using logarithmic transformation, $\log (\mathrm{x}+1)$.

\section{Results and Discussion}

Average litter amounts $\left(1,730\right.$ and 1,500 $\mathrm{g} \mathrm{m}^{-2}$ at survival and exterminated plots, respectively) and water contents (57.8 and $73.7 \%$ ) were not significantly 
different in November samples, but there was somewhat higher water content in extermination plots.

Ants (Formicidae) were the most dominant soil macrofauna irrespective of season and type of plot; their percentage in total macrofauna ranged from 23.8 to $53.8 \%$. The average density of ants ranged from 52 individuals $\mathrm{m}^{-2}$ to 191 individuals $\mathrm{m}^{-2}$, and was not significantly different between land snail survival and extermination plots (Figure 1). Twelve and 16 species of ants were found in survival plots and extermination plots, respectively. Ten species were found in both types of plot. The two species that were found only in survival plots were pantropical and common to the Honshu mainland.

Earthworms (Order Haplotaxida) were the second largest group of soil macrofauna; the percentage ranged from 9.3 to $24.6 \%$ of specimens. The average density of earthworms ranged from 33 individuals $\mathrm{m}^{-2}$ to 89 individuals $\mathrm{m}^{-2}$, and was significantly larger at extermination plots (Figure 1). Four and five species of earthworms were found in survival plots and extermination plots, respectively, with four species common to both types of plot. The average fresh weight of the earthworms ranged from 8.1 to $15.2 \mathrm{~g} \mathrm{~m}^{-2}$ ( 0.71 to $1.49 \mathrm{~g} \mathrm{~m}^{-2}$ in weight), and was not significantly different between plot types.

Isopods were relatively rare in the soil macrofauna, ranging from 1 to $6.1 \%$. The average density of isopods ranged from 2.7 individuals $\mathrm{m}^{-2}$ to 22 individuals $\mathrm{m}^{-2}$, and was significantly larger at extermination plots (Figure 1). Two and five species of isopods were found in survival plots and extermination plots, respectively.

The density of beetles ranged from 6.2 individuals $\mathrm{m}^{-2}$ to 16 individuals $\mathrm{m}^{-2}$, and was not significantly different between types of plot (Figure 1). Four and nine species of beetles were found in survival plots and extermination plots, respectively. Only two species were common; and two species were found only in survival plots. One of the species found only in survival plots was an undescribed but land snail-selective feeding carabid beetles (Badister sp.).

Millipedes (Diplopoda: Arthropoda) increased their abundance in November at extermination plots (18\%), and reached the average density of 59 individuals $\mathrm{m}^{-2}$. Species richness of earthworms, isopods, ants and beetles was not significantly different between plot types.
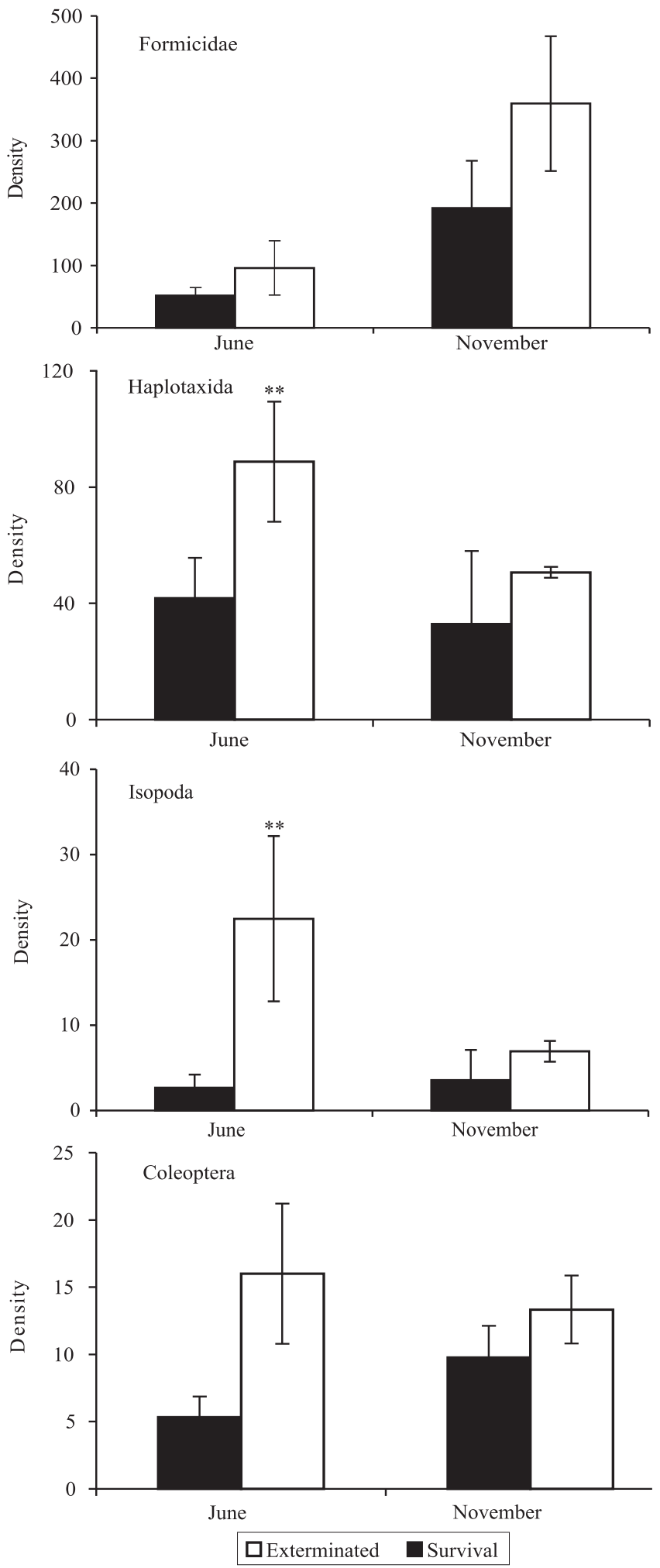

Figure 1. Average density (number of individuals per $\mathrm{m}^{2}$ ) of ants (Formicidae), earthworms (Haplotaxida), isopods (Isopoda), beetles (coleoptera), in areas where land snails had survived or were exterminated. Bars indicate standard errors. **Significant difference between plot types at $1 \%$ of probability. 
The average density of Collembola ranged from 5,700 individuals $\mathrm{m}^{-2}$ to 24,100 individuals $\mathrm{m}^{-2}$; the density in each plot was significantly larger in land snail survival plots both in June and November (Figure 2). Thirty-seven and 38 species of Collembola were found in survival and in extermination plots, respectively. Eight species of Collembola were found in both types of plot. Seven species of Collembola found only in survival plots appeared to be rare and undescribed.

The average density of Oribatida ranged from 15,100 individuals $\mathrm{m}^{-2}$ to 37,000 individuals $\mathrm{m}^{-2}$; the density was not significantly different between plot types (Figure 2). Oribatid mite density in November was significantly and negatively correlated with earthworm density $(0.86, p=0.028)$. Eighty-four and 88 species of Oribatida were found in survival and in extermination plots, respectively. Sixty-nine species of Oribatida were found in both types of plots. Eleven out of 15 species found only in survival plots are also recorded in the Honshu mainland, two ones are recorded in other Pacific islands, and two are unidentified. Species richness of Collembola and Oribatida was not significantly different between plot types.

Survivaland extermination plots were relativelywell defined in PCA ordination diagrams for communities of earthworms, ants, Collembola and Oribatida (Figure 3 A, D and Figure 4). For communities of isopods and beetles, the separation of plot types was unclear, probably because of the low abundance of adults in the samples (Figure $3 \mathrm{~B}, \mathrm{C}$ ). Most of the earthworm species were associated with extermination plots (eigenvalue for axis 1 and 2, 0.52 and 0.33). In isopods, Trichorhina sp. was associated with one survival plot (eigenvalue for axis 1 and 2, 0.78 and 0.16). In ants, Monomorium sechellense and Pheidole bugi were associated with extermination plots, while Pheidole fervens and Pristomyrmex pungens were associated with survival plots (eigenvalue for axis 1 and 2, 0.48 and 0.27). In Coleoptera, Badister sp. was associated with plot B (survival) (eigenvalue for axis 1 and 2, 0.76 and 0.13). In Collembola, Ceratophysella denticulata and Alloscopus tenuicornis were associated with extermination plots, while Folsomides parvulus and Isotomiella sp. were evenly distributed between the two types of plot (eigenvalue for axis 1 and 2, 0.58 and 0.19) (Figure 4 A). In Oribatida, Rostrozetes ovulum and Hermanniella yasumai were associated with survival plots, while Multioppia sp.1 was associated with extermination plots (eigenvalue for axis 1 and 2, 0.48 and 0.27) (Figure $4 \mathrm{~B}$ ).

The selective land snail-feeding carabid beetle (Badister sp.) was found only in land snail survival areas. This indicates that the extinction of land snails might cause the successive extinction of other species. The population of Badister sp. around the Ogasawara Islands, in areas with and without land snails, needs to be monitored for the conservation of the species.

Overall, soil fauna had no decrease in density or species richness in extermination areas, and some groups (earthworms, isopods and collembolans) had even a higher density. The somewhat higher water content in extermination plots might have led to the higher density of some groups in extermination areas.

The PCA showed subtle differences in species composition, in some taxonomic groups, between survival and extermination plots, but these differences

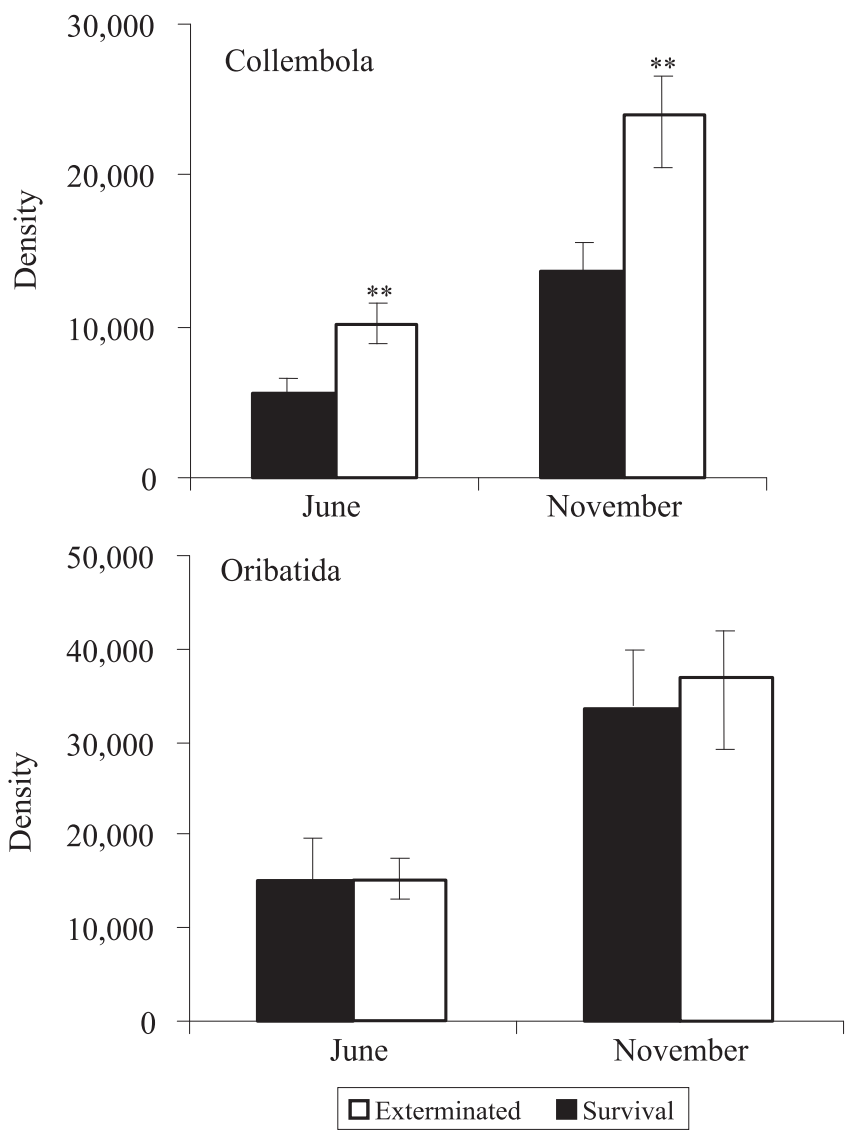

Figure 2. Average density (number of individuals per $\mathrm{m}^{2}$ ) of Collembola and Oribatida, in areas where land snails had survived or were exterminated. Bars indicate standard errors. **Significant difference between types of sites at $1 \%$ of probability. 
were not due to the presence or absence of endemic species, except for the case of Badister sp. In the present study, the survival plots were clustered together, thus the differences might have been due to the response of each species in the community to the environmental
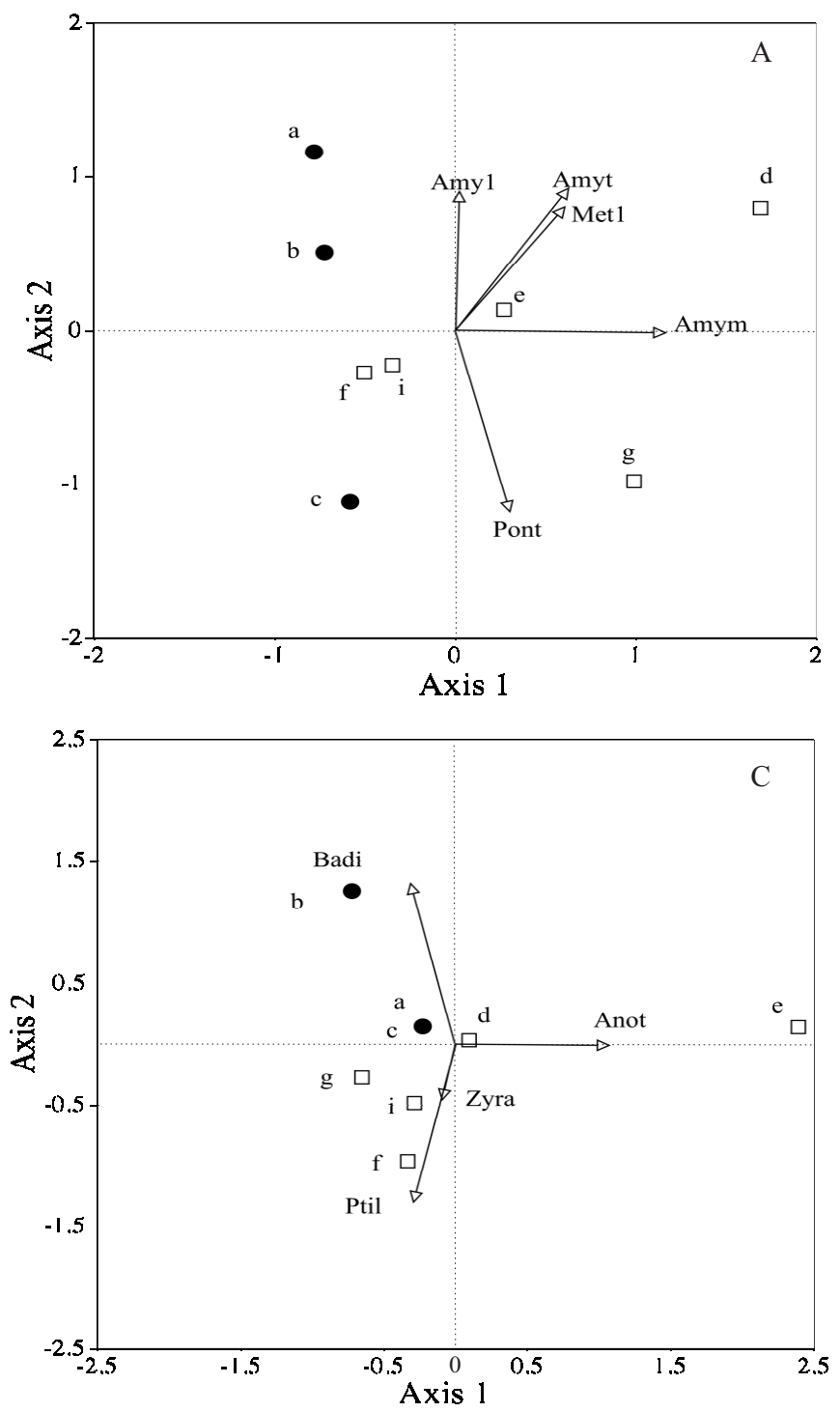

factors of the respective areas, regardless of the presence or absence of land snails and flatworms. Besides, invasive species of earthworms and ants had already been spread over the island, irrespective of the predatory flatworms.
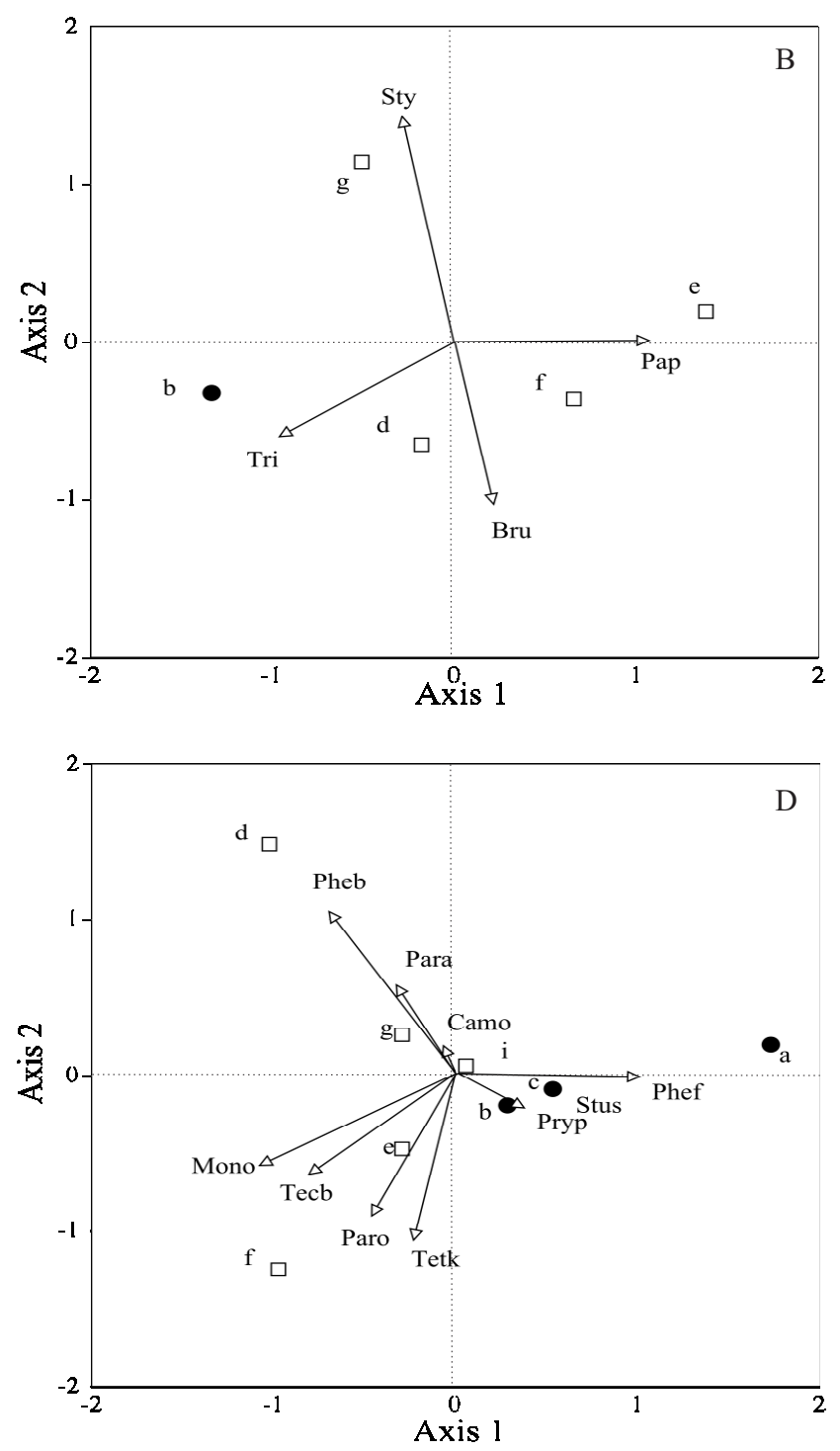

Figure 3. Principal component analysis ordination diagrams for: (A) earthworms, (B) isopods, (C) beetles and (D) ants. Values averaged from June and November were used. The placement of black circles (survival plots) and white squares (extermination plots) reflects the similarity of the communities at the sites. Arrows indicate the direction associated with the dominant species of each community. Key for the dominant species names in each community are as follows: A) Amy1, Amynthas sp.1; Met1: Metaphire sp.1; Amym, Amynthas minimus; Amyt, Amynthas tokioensis; Pont, Pontoscolex corethrurus; B) Bru, Brumoniscus okinawaensis; Pap, Papuaphiloscia sp.; Sty, Styloniscidae; Tri, Trichorhina sp.; C) Anot, Anotylus glareosus; Badi, Badister sp.; Ptil, Ptilodactyla sp.; D) Mono, Monomorium sechellense; Pheb, Pheidole bugi; Phef, Pheidole fervens; Paro, Paratrechina ogasawarensis; Pryp, Pristomyrmex pungens; Camo, Camponotus ogasawarensis; Tetk, Tetramorium kraepelini; Stus, Strumigenys solifontis; Para, Paratrechina amia; Tecb, Technomyrmex brunneus. 
Earthworms had high densities in all plots in this study. Many species of earthworms are killed by even brief immersion in sea water (Lee, 1981). Indeed, the absence of native earthworms from mid-oceanic volcanic islands, such as the Hawaiian and Canary Islands, shows that earthworm immigration to oceanic islands is uncommon (González et al., 2006). There is no evidence that the Ogasawara Islands have ever been connected to any other land surface; they must be regarded as true oceanic islands. Thus, all earthworm species found in this study have likely been translocated by human activity (Nakamura, 1994). The density and biomass of earthworms, in the present study, were comparable to the average values given for tropical rain forests ( 68 individuals $\mathrm{m}^{-2}$ and $12.9 \mathrm{~g} \mathrm{~m}^{-2}$ ) by Fragoso \& Lavelle (1992). Ohbayashi et al. (2005) reported that the predatory flatworm $P$. manokwari fed not only on live land snails but also on carcasses of earthworms. Thus, they assumed that $P$. manokwari would survive even if the populations of land snails were almost completely lost on Chichijima Island in the future. In the present study, this assumption was supported by the finding that the earthworm biomass

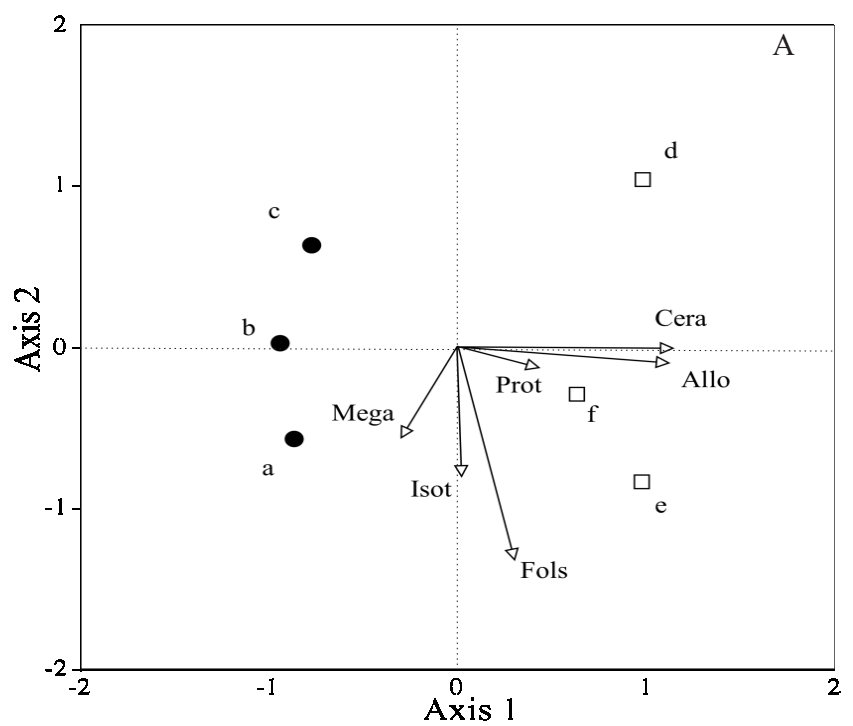

seems sufficient. Typical invasive earthworm species such as Pontoscolex corethrurus and Amynthas minimus are found in the Pacific islands and were dominant in the communities surveyed in the present study. P. corethrurus accounted for about $80 \%$ of all the identified earthworm specimens and about $16 \%$ of total earthworm fresh biomass.

González et al. (2006) reported 400 and 800 individuals $\mathrm{m}^{-2}$ as the maximum values for densities of $P$. corethrurus in Central and South America, and described their significant influence on local ecosystems and soil properties. Migge-Kleian et al. (2006) suggested that, in the longer term, the activity of invading earthworms could have a strong negative impact on indigenous faunal groups across multiple trophic levels. In the present study, the density of earthworms was less than that reported for Central and South America. Severe environmental conditions (for example summer drought) may inhibit the explosive increase of the fauna. But even at the low island-typical levels, the Oribatid mite density was negatively correlated with earthworm density in November. Thus, the invasion of earthworms may decrease the density

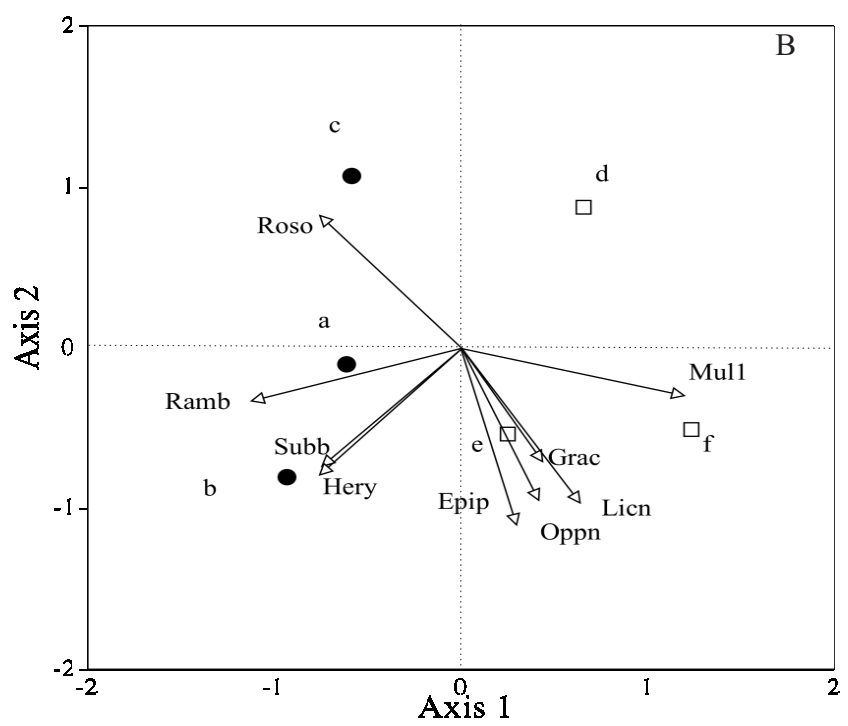

Figure 4. Principal component analysis ordination diagrams for: (A) Collembola and (B) Oribatida. Values averaged from June and November were used. The placement of black circles (survival plots) and white squares (extermination plots) reflects the similarity of communities at the sites. Arrows indicate the direction associated with the dominant species of each community. Key for the dominant species names in each community are as follows; A) Fols, Folsomides parvulus; Cera, Ceratophysella denticulata; Isot, Isotomiella sp.1; Prot, Protaphorura sp.1; Meaga, Megalothorax minimus; Allo, Heteromurus (Alloscopus) tenuicornis; B) Epip, Epilohmannia pallida pacifica; Mul1, Multioppia sp.1; Grac, Graptoppia cristata; Subb, Subiasella boninensis; Oppn, Oppiella nova; Hery, Hermanniella yasumai; Ramb, Ramusella bicillata; Licn: Licneremaeus novaeguineae; Roso, Rostrozetes ovulum. 
of Oribatid mites. Studies that examine the effects of earthworms on ecosystem properties and native biodiversity are needed.

Invasions by nonnative ants are an ecologically destructive phenomenon affecting both continental and island ecosystems throughout the world (Holway et al., 2002). The yellow crazy ant (Anoplolepis gracilipes) and big-headed ant (Pheidole megacephala) are typical species which invade island ecosystems (Holway et al., 2002; O'Dowd et al., 2003). These two ants were not collected in the present study, but other tramp (alien or introduced) species (Pheidole bugi, Pheidole fervens and Technomyrmex brunneus) were detected, and these three species accounted for $30 \%$ of all ants found in the present study. The effect of these tramp ant species on ecosystem properties and native biodiversity are unknown.

Nunomura (1991) indicated that ten of the twelve isopod species known in Ogasawara Islands are endemic. Kobayashi et al. (1970) reported an extremely high abundance of isopods $(20 \%$ of total abundance of soil animals), from a pitfall trap census. According to a hand sorting census conducted by Aoki \& Harada (1978), the average density of isopods in 11 forest sites in Chichijima was calculated to be 1,153 individuals $\mathrm{m}^{-2}$, and was $59 \%$ of total abundace of soil animals (957 individuals $\mathrm{m}^{-2}$ and $60 \%$ of total abundance in a Livistona chinensis forest). Thus, the density of isopods is thought to have been extremely high until the 1970s, in Chichijima. In contrast, the average density of isopods in the present study was very low. Ishizawa \& Takehara (2001) also reported low density (11.4 individuals $\mathrm{m}^{-2}$ and $0.9 \%$ in dominance). These reports indicate that, during the late 1990s, the density of isopods had been reduced. The reasons for this decrease are unknown. Ishizawa \& Takehara (2001) speculated that the decrease was attributable to extreme drought in the soil surface, during an extremely low rainfall period in 1980 , destruction of the forest crown by a typhoon in 1983, and mass die-back of Pinus luchuensis by the pine-wilt disease, beginning in the 1980s. In addition, predation by invasive animals (such as giant toads) or indirect loss of forest floor litter by earthworms could be a cause of the decrease. The colonization of giant toads (Bufo marinus) was confirmed before the 1970s. However, the density of isopods at that time was known to be high (Aoki \& Harada, 1978), and there was no apparent impact of the toads on isopods. The dominant prey of the giant toads (Bufo marinus) were (by weight) the giant African snail (Achatina fulica), isopods and Diptera larvae (Matsumoto et al., 1984). By 2001, the population of the giant African snail had decreased dramatically from the level in 1985, and its distribution had diminished, probably because of the invasion of Platydemus manokwari and the low fecundity of the snail (Ohbayashi \& Takeuchi, 2007). The shortage of the food resources may have caused a shift in the toad's feeding habits from giant African snails and insects to isopods. Manipulative studies of environmental variables and absence or presence of these invasive species may help to reveal the cause of the decline of isopods.

\section{Conclusions}

1. Much of the soil fauna remains undiminished, however, one undescribed but endemic carabid (Badister sp.), which selectively feeds on land snails, is absent in snail-extinct areas. Endemic isopods have also become reduced, but the cause remains unclear.

2 . The present community of soil animals is dominated by introduced earthworms and tramp species of ants.

\section{Acknowledgements}

To Dr. Mamoru Terayama, Dr. Kyouichi Kinomura and Dr. Kei Ichisawa for identifying specimens. To the staff of the National Forest Division of the Ogasawara General Office, the Board of Education of the Ogasawara Village Office, Keita Fukazawa and the staff of Mulberry, for the field sampling. This study was supported by the Global Research Fund (F-051) of the Ministry of the Environment, Japan.

\section{References}

AOKI, J. New carabodid mites (Acari: Oribatei) from the Bonin Islands. Memoirs of the National Science Museum, v.11, p.81-89, 1978.

AOKI, J.; HARADA, H. Investigations on soil fauna of the Bonin Islands. I. Soil arthropod communities. Memoirs of the National Science Museum, v.11, p.91-106, 1978.

CHIBA, S.; DAVISON, A.; MORI, H. Endemic land snail fauna (Mollusca) on a remote peninsula in the Ogasawara Archipelago, Northwestern Pacific. Pacific Science, v.61, p.257-265, 2007.

FRAGOSO, C.; LAVELLE, P. Earthworm communities of tropical rain forests. Soil Biology and Biochemistry, v.24, p.1397-1408, 1992. 
GONZÁLEZ, G.; HUANG, C.Y.; ZOU, X.M.; RODRÍGUEZ, C. Earthworm invasions in the tropics. Biological invasions, v.8, p.1247-1256, 2006

HOLWAY, D.A.; LACH, L.; SUAREZ, A.V.; TSUTUI, N.D.; CASE T.J. The causes and consequences of ant invasions. Annual Review of Ecology and Systematics, v.33, p.181-233, 2002.

ISHIZAWA, Y.M.; TAKEHARA, A. Maintaining mechanism of organism diversity in islands. Community structure and stability of macro soil animals in Chichi-jima of the Ogasawara Islands. Research Report from the National Institute for Environmental Studies, v.158, p.117-120, 2001.

KOBAYASHI, S.; NISHIMORI, M.; YAJIMA, T.; KATO, M. The arthropod fauna of Bonin Islands surveyed by the bait traps. In: The Nature of the Bonin and the Volcano Islands. Tokyo: Ministry of Education, Culture, Sports, Science and Technology and Agency for Cultural Affairs, 1970. p.33-44.

LEE, K.E. Earthworms (Annelida: Oligochaeta) of Vanua Tu (New Hebrides Islands). Australian Journal of Zoology, v.29, p.535-572, 1981.

MATSUMOTO, Y.; MATSUMOTO, T.; MIYASHITA, K. Feeding habits of the marine toad, Bufo marinus, in the Bonin Islands, Japan. Japanese Journal of Ecology, v.34, p.289-297, 1984.

MIGGE-KLEIAN, S.; MCLEAN, M.A.; MAERZ, J.C.; HENEGHAN, L. The influence of invasive earthworms on indigenous fauna in ecosystems previously uninhabited by earthworms. Biological Invasions, v.8, p.1275-1285, 2006.

NAKAMURA, M. Earthworms (Annelida: Oligochaeta) of Ogasawara Archipelagoes. Chuo Daigaku ronshu, v.15, p.21-32, 1994.

NUNOMURA, N. Isopoda in Ogasawara Islands. In: ONO, M.; KIMURA, M.; MIYASHITA, K.; NOGAMI, M. (Ed.). Report of the second general survey on natural environment of the Ogasawara (Bonin) Islands, 1990-1991. Tokyo: Metropolitan University, 1991. p.227-230.
O'DOWD, B.J.; GREEN, P.T.; LAKE, P.S. Invasional "meltdown" on an oceanic island. Ecology Letters, v.6, p.812-817, 2003.

OHBAYASHI, T.; OKOCHI, I.; SATO, H.; ONO, T. Food habit of Platydemus manokwari De Beauchamp, 1962 (Tricladida: Terricola: Rhynchodemidae), known as a predatory flatworm of land snails in the Ogasawara (Bonin) Islands, Japan. Applied Entomology and Zoology, v.40, p.609-614, 2005.

OHBAYASHI, T.; OKOCHI, I.; SATO, H.; ONO, T.; CHIBA, $\mathrm{S}$. Rapid decline of endemic snails in the Ogasawara Islands, Western Pacific Ocean. Applied Entomology and Zoology, v.42, p.479-485, 2007.

OHBAYASHI, T.; TAKEUCHI, K. Fluctuation of the distribution and population of the giant African snail, Achatina fulica Bowdich (Pulmonata: Achatinidae) in Chichijima and Hahajima Islands, of the Ogasawara (Bonin) Islands, from the years 1995 to 2001. Japanese Journal of Applied Entomology and Zoology, v.51, p.221-230, 2007.

OKOCHI, I.; SATO, H.; OHBAYASHI, T. The cause of mollusk decline on the Ogasawara Islands. Biodiversity and Conservation, v.13, p.1465-1475, 2004.

SILESHI, G. The excess-zero problem in soil animal count data and choice of appropriate models for statistical inference. Pedobiologia, v.52, p.1-17, 2008.

SUGIURA, S.; OKOCHI, I.; TAMADA, H. High predation pressure by an introduced flatworm on land snails on the oceanic Ogasawara Islands. Biotropica, v.38, p.700-703, 2006.

TER BRAAK, C.J.F.; ŜMILAUER, P. CANOCO reference manual and canodraw for Windows user's guide: software for Canonical Community Ordination. Version 4.5. Ithaca: Microcomputer Power, 2002.

TOYODA, T. Floral of Bonin Islands: enlarged and revised. Kamakura: Apoc, 2003.

WARDLE, D.A. Islands as model systems for understanding how species affect ecosystem properties. Journal of Biogeography, v.29, p.583-591, 2002.

Received on September 25, 2008 and accepted on January 16, 2009 